\title{
BLOGGERS, COPYRIGHTS AND SOME OTHER LEGAL ISSUES
}

BLOGUEROS, DERECHOS DE AUTOR Y ALGUNAS OTRAS CUESTIONES LEGALES

\author{
Alla Kyryliuk ${ }^{*}$ \\ Viktoriia Lysenko** \\ Alina Podolieva***
}

\begin{abstract}
The purpose of the study is to find out the place of the blog in the field of copyright; identification the most pressing problems that may arise as a result of blogging; and finding the most effective approaches and options to solve the above problems. The object of research is the system of national and foreign legislation, legal doctrine, bills in the field of intellectual property, and copyright. Empirical methods such as observation and description and theoretical methods such as analysis, synthesis, generalization, and explanation were used in this work. The work has the following structure: first, it takes care of the differences in understanding of copyright regulation in different legal systems, the world experience in regulating intellectual property, and its history. Then, blog copyrights are analyzed, as well as online copyright infringement, ways to protect content, and some other actual realities. As a result of the study of the intellectual property legislation that governs this subject - in particular, in the field of copyright and related rights - there is a clarification of the notion of "blog"
\end{abstract}

\footnotetext{
* Ph.D., Associate Professor of Intellectual Property and Corporate Law Department of National University “Odesa Law Academy” (Odesa, Ukraine). https://orcid.org/0000-00023051-6599. kyryliuk.alla@gmail.com

** Ph.D. candidate of Civil law Department of National University "Odesa Law Academy" (Odesa, Ukraine). https://orcid.org/0000-0002-7200-4954. vikusya7894@gmail.com

*** Ph.D. candidate of Intellectual Property and Corporate Law Department of National University "Odesa Law Academy" (Odesa, Ukraine). https://orcid.org/0000-0002-54943640. a.podolieva@gmail.com
} 
and the regulation that governs blogging in Ukraine is identified. In addition, some practical recommendations were given to bloggers on legal protection of their copyrights.

Keywords: Copyright, Intellectual Property, Personal Blog, Internet, Social Networks

Resumen: El propósito del estudio es conocer el lugar del blog en el campo de los derechos de autor, identificar los problemas más urgentes que los blogueros tienen, a fin de encontrar los enfoques y opciones más eficaces para resolver estos problemas. Se investigan aquí la legislación nacional y extranjera, la doctrina jurídica, y varios proyectos de ley sobre propiedad intelectual y derechos de autor. El análisis acude a métodos empíricos como observación y descripción, y teóricos como análisis, síntesis, generalización y explicación. El trabajo tiene la siguiente estructura: comienza analizando los diferentes sistemas de derechos de autor y la experiencia mundial en la regulación de la propiedad intelectual, y su historia. Luego se ve la regulación de los derechos de autor del blog; las infracciones de estos derechos realizadas en línea; las diversas formas de proteger el contenido, entre otras realidades actuales. Como resultado del estudio de la legislación que rige la propiedad intelectual en esta materia -y en particular, en el campo de los derechos de autor y afines-, se aclara el concepto de "blog" y se identifica el estatuto jurídico que regula los blogs en Ucrania. Además, se dan recomendaciones prácticas a los blogueros sobre la protección legal de sus derechos de autor.

Palabras clave: Derechos de autor, propiedad intelectual, blog personal, internet, redes sociales

Summary. I. Introduction. II. Analysis of recent research. III. Results and Discussion. III.1. Differences in Copyright Regulation in the Main Legal Systems. a) An object. b) Related rights. c) Originality. d) Subject. e) Fair and free use. III.2. Historical Experience in Regulating Intellectual Property. III.3. Blog Copyright. III.4. Online Copyright Infringement. III.5. Ways to Protect Content. III.6. The Realities of Today. IV. Conclusions. References.

\section{INTRODUCTION}

The fact of human existence in society as its constituent element has led to the emergence of a set of envisaged, defined, and enshrined natural inviolable human freedoms and their legal capabilities, which in turn, the 
international and national legislature defines as human rights. Based on the realities of today, we can trace the significant influence of the human rights institution on the formation of policy, economy, and overall development strategy in any modern state.

Human rights are inalienable and inalienable. Human rights define the person as the highest social value. Moreover, human rights outline the limits of personal freedom, contribute to the establishment of a socio-legal regime for its provision and implementation, and coordinate it in the relationship of the individual with society and the state.

The list of human rights in Ukraine is established and guaranteed by the main law, the Constitution of Ukraine (1996). Also, special rights are reflected in other regulations, for example: in the Civil Code of Ukraine (2003), the Civil Procedure Code of Ukraine (2004), the Administrative Procedure Code of Ukraine (2005), among others.

Ukraine has established the primacy of universally recognized principles and norms of international law over national legislation in general political activity. This means that if an international convention, agreement, treaty, or international law norm in another sense has been adopted and ratified by the Parliament, the Verkhovna Rada of Ukraine, then such a norm must be implemented, i.e., added, to national legislation in such a way as to ensure the priority of the international norm. over the national. A clear example of such a priority is the Convention for the Protection of Human Rights and Fundamental Freedoms (1950), which was ratified by the Verkhovna Rada of Ukraine in 1997. Today, the principles of human rights guaranteed by the above-mentioned Convention are fundamental. One of the guarantees of this legal act is the right to freedom of thought and freedom of expression. In turn, in case of their violation, every citizen, foreigner, or stateless person can apply to the European Court of Human Rights to protect and restore violated, disputed, or unrecognized rights.

The Institute of Human Rights is quite broad and includes several areas, in particular, the field of intellectual property protection and copyright. The Constitution of Ukraine in Article 41 establishes and guarantees the right of everyone to own, use, and dispose of their property, the results of their intellectual and creative activities. Article 54 of the Constitution of Ukraine contains an indication of the guarantee of freedom of literary, artistic, scientific, and technical creativity, protection of intellectual property, their authors, moral and material interests arising in connection with various types of intellectual activity. Analyzing these provisions, we can conclude that copyright is one of the fundamental human rights and is protected by the state from encroachment. 
An important feature of modern state formation is that it has undergone significant changes due to the introduction of new technologies. The main change is the possibility of rapid dissemination of information via the Internet, which has led to a significant increase in the role of information resources in any area of life and activity. Such changes have also affected the legal system, in particular, the human rights institution, which includes the individual's right to intellectual property and copyright.

The Internet has not only become widely used, but also has become an integral resource for any activity in various spheres of society. In today's realities, the Internet is a platform for both economic and creative or scientific activities.

Internet technologies expand the ability of users not only to receive but also to share information. However, downloading, storing, disseminating certain information may be illegal, as such actions may be carried out with objects that are protected by copyright. This issue is quite complex and complex, therefore, requires detailed study and resolution. It is important not only to know how to protect copyrights but also to understand how not to infringe them, as current legislation provides for sanctions for such illegal actions.

Also, with the development of the Internet, social networks have gained rapid popularity among users, where everyone can share certain information in the form of a post (i.e., short text), photos, videos, and more. Particularly popular today are personal blogs on social networks such as Instagram, Facebook, YouTube, or Twitter or blogs, which in their form are websites that contain certain multimedia, which, in turn, is constantly added. The main purpose of blogs is to disseminate information.

The Cambridge Dictionary (2020) explains the term "blog" as a regular record of your thoughts, opinions, or experiences that you put on the internet for other people to read. The Macmillan Dictionary (2020) contains the following explanation: "blog" is a website containing short articles called posts that are changed regularly.

Quite often, there are copyright infringements in the space of social networks due to the use of bloggers' posts (bloggers). This offense is usually due to a lack of awareness, as not all users are aware of the subject and application of copyright on the Internet. From this follows the need to understand the problem in more detail.

\section{ANALYSIS OF RECENT RESEARCH}

The topic of bloggers' copyright protection is not widely explored as a separate legal aspect. Most lawyers and scholars have explored relevant 
issues, such as intellectual property issues, strategies to improve copyright law due to the global spread of the Internet, what gaps in media legislation exist today, and what effective ways to fill them with innovations. That is why we can highlight the novelty of the study of the activities of bloggers as participants in legal relations in the field of intellectual property.

However, for example, Cox and Blake (2011) in the article "Information and food blogging as serious leisure" studied the problem of intellectual property right on food blogging, personal data protection, the authorship. They noted that pre-professionals had an intensified concern with Intellectual Property Rights.

In resent research the topic was studied by Kaminsky (2020). The work deals with the main ideas of copyright protection and focuses on the specific notion in this area.

Nevertheless, the very topic of intellectual law is widely studied. The term "intellectual property" was first used by an American judge of the Massachusetts District Court in 1845, Charles Woodbury (United States, 1845). In continental Europe, the term was first used by Alfred Nyon in the work Droits civils des auteurs, artistes et inventeurs (1846).

Among modern Ukrainian researchers who have deeply studied intellectual law is the chief forensic expert on intellectual property Aksyutina, Nestertsova-Sobakar \& Tropin, (2017). The lawyers placed the results of their research in the manual "Intellectual Property", which systematizes the main provisions of the legislation of Ukraine on intellectual property. Also, the results of his research were presented in a textbook entitled "Intellectual Property Law", Doctor of Law Svitlychny (2016). The professor described the general provisions on intellectual property rights, sources, objects and subjects, subject, state system of protection of intellectual property rights.

Rishkova (2007) in the dissertation entitled "Protection of intellectual property rights under the civil legislation of Ukraine" considered the place of intellectual property under the civil legislation of Ukraine. The researcher spoke about the peculiarities of intellectual property management and intellectual property, defined the concepts and types of legal remedies, types of liability for infringement of intellectual property rights and measures to protect infringed intellectual property rights, formulated proposals to improve the civil law of Ukraine.

Moreover, Niculesco (2019) researched the development strategies of Ukraine in the field of intellectual property. In his publication, the lawyer spoke about the key aspects of national legislation that need to be reformed and the prospects of the reform itself. Moreover, the lawyer singled out the main problems of Ukraine's intellectual property identified after the 
Revolution of Dignity. Also, Niculesco (2019) spoke about the reorganization of public administration.

Ways to protect copyright on the Internet reveals in his publication the former Deputy Minister of Justice of Ukraine, Moroz (2019). The lawyer focused on ways to obtain compensation in case of copyright infringement online. In addition, the lawyer conducted an analysis of judicial protection in this area.

Methods of copyright protection were researched by Koval (2020). The lawyer revealed the issue of copyright protection in Ukraine, based on the annual report of the European Commission on the protection and enforcement of intellectual property rights. Moreover, Koval (2020) spoke about preventive measures to protect copyright and their relevance.

Other researchers of the theoretical basis of this field of law are such domestic and foreign scholars as Grigorenko (2019), Zakusilo (2020), Zerov (2018), Zozulya (2019), Safarov (2020), Nedoinov and Kruglova (2019).

\section{RESULTS AND DISCUSSION}

\section{III.1. Differences in Copyright Regulation in the Main Legal Systems}

Intellectual property is a set of rights of a person to the results of his work in scientific, creative, industrial, and other activities in those areas that are the object of civil relations. The rights of the author extend to the possession, use, and disposal of the product, which arose as a result of his intellectual activity. Historically, there have been two approaches to intellectual law advising the Romano-Germanic and Anglo-Saxon legal systems. Depending on your country of residence, place of publication, registration of the resource that you are using, there may be a different interpretation of copyright, so it is recommended that you familiarize yourself with the specifics of legal regulation in different systems. Let's briefly consider their features.

\section{a) An object}

In the continental copyright system, the objects of copyright are any works of art that are original. Here, the legislative list of the types of art to which a protected work may belong is approximate, i.e., unclosed. The title of a work is also subject to protection as an object of copyright if it is the result of the creative activity of the author (original) and can be used independently. 
In countries adhering to the Anglo-Saxon copyright system, the legislative list of protected works is, as a rule, exhaustive, it «almost leaves the courts with no maneuver to recognize the protection of works of other types» (Bently, Sherman, Gangjee \& Johnson, 2018). However, this matter does not really affect the rights of bloggers.

\section{b) Related rights}

The next feature of the classical Romano-Germanic legal tradition is the fact that the sphere of legal regulation of art here is divided into an institution that protects creative works (copyright), and an institution that protects the performance of these works by artists, as well as phonograms (related rights).

Anglo-American law, unlike continental law, does not fundamentally distinguish between the protection regimes for works of art and performances, phonograms. This leads to the fact that the copyright of the countries of the copyright system is applied to values that may not be creative works (Liptsik, 2002). Here, all kind of bloggers' creations and posts could be covered by the same rights.

\section{c) Originality}

Another difference between the considered concepts is the degree of originality required for a particular work of art to receive the status of an object of copyright. In general, originality is only one of the possible criteria for creativity, but it was this that became the cornerstone of copyright in deciding the issue of protecting artistic works. Legislators in all countries avoid defining the concept of "originality". The field where this card is played is legal doctrine and jurisprudence.

In the countries of Anglo-Saxon law, "originality" is understood primarily as an expression of the author's personality (Baldwin, 2014). This very broad definition has received many interpretations. For example, according to one of them, the expression of the author's personality is considered simply as a manifestation of the individuality of the one who created the work. «In this case, an original work can also be defined as a work that does not have a copy, created by a certain person, and not by someone else» (Matveev, 2009). The dominant interpretation of originality in the Romano-Germanic legal tradition is considered to be another: a subjective, romantic concept. From this point of view, only one in which the author was able to express his feelings, emotions, and fantasies is considered an original work. 
In the common law tradition, the concept of originality, called "objective", has been established. Here the work receives legal protection even with such a minimum of signs of creative activity, which allows us to say that it has not been copied. The English and American courts, to determine whether a particular work is original, raise the question of how much work, skill, or effort the author put into creating this product. The objective concept was aphoristically expressed by one of the English judges of the early twentieth century as follows: what is worthy of reproduction should be considered worthy of protection. Probably it means a broader protection for some posts of bloggers that lacks some degree of originality, as a retouched photo, resized pictures, wish lists, and some databases. Many of these things hardly will pass the Romano-Germanic test of originality.

\section{d) Subject}

Anglo-American and Romano-Germanic legal traditions address the question of who may be the original owner of the rights to a work of art in different ways. The classic postulate of the New Age, which says that only a person can be a subject capable of performing an act of artistic creation, was continued in the natural law maxim: the original owner of the rights to a work of art should be only the author. Continental copyright, as noted above, is built around this principle. Here, with some exceptions, the rights to a work of art can initially arise only in the person whose creative labor it was created. Thus, in the Romano-Germanic legal tradition, the culturological and legal concepts of "author", by and large, coincide.

In countries belonging to the common law family, the legal concept of "author" is considered broader than in legal systems based on the tradition of Roman law. Here, when it comes to creating a work on the basis of an employment contract, by order or for the purpose of using it in the production of films and other collective works, the employer, customer, the producer is legally recognized as the author and, accordingly, the original copyright holder of the subjective rights to the specified product. Thus, in the United States, §201b of the Copyright Act of 1976 states:

«In the event of a creation of a work for hire, the employer or other person for whom the work was created shall be considered the author in the sense of this Act and, unless the parties specifically stipulate otherwise in the document signed by them, has all the powers of copyright».

Such a fiction, when the author is recognized as a person who did not make a creative contribution to the creation of a work of art, was called in the doctrine "the concept of employment". The latter is especially developed 
in the United States, where it is extremely disadvantageous for the American film production, publishing, and printing industries that creators of works retain not only property but also personal non-property rights. According to the concept of employment, all persons involved in the production of, for example, a motion picture, even those whose inspiration, script, and direction created it, are contracted employees. Unless otherwise provided by the employment agreement, the copyright company is allowed to modify the work regardless of the interests of those whose creative work it was created.

\section{e) Fair and free use}

In the countries of the Anglo-Saxon legal system, copyright law has the concept of fair use or fair dealing. It is a legal doctrine that describes the exceptions and limitations of the exclusive right granted to the author of creative work by law. This doctrine allows the free use of copyrighted material subject to certain conditions. So the use of protected works is not a violation of copyright, including the reproduction of works (including audio recordings) for the purpose of criticism, commenting, news coverage, teaching (including reproduction for use in the classroom), teaching or scientific research is not recognized as an infringement. In determining whether the use of a work is in good faith on a case-by-case basis, the following factors should be taken into account: (i) the purpose and nature of the use, including whether the use is commercial in nature or is for noncommercial educational purposes; (ii) the nature of the work protected by copyright; (iii) the size and materiality of the part used in relation to the entire work protected by copyright; and (iv) the impact of the use on the potential market or value of the copyrighted work.

Due to the fact that the doctrine of fair use was born in common law countries, in civil law countries (including Ukraine), there is no such legal institution, but there is a similar analog in meaning - free use of a work. The main difference between "fair" and "free" use is that in the first case absolutely any use of the work is allowed if such use is recognized as "fair" according to the criteria described above, and in the second case only in cases clearly limited by law, for example, in arts. 21-25 Law of Ukraine "On copyright and related rights" (1993) the following options are mentioned: (i) free reproduction of a work for personal purposes; (ii) free use of the work for informational, scientific, educational or cultural purposes; (iii) free public performance of a lawfully published piece of music; (iv) free reproduction of a work for the purposes of law enforcement; and (v) free recording of a work by a broadcasting organization for short-term use. 
Having considered these features, we conclude that each of the systems has its pros and cons for different players. Copyright in the RomanoGermanic system is more streamlined and unified, the influence of court decisions is limited, and the author has copyright to the work in the established volume and legal terms, no more, no less.

In turn, the Anglo-Saxon copyright system has many loopholes and conditions that can both bring additional profit to the author, and leave him with nothing. For example, the precedent of Paul McCartney (Southern District of New York, 2017), who, having lost the rights to his songs in the Beatles, was forced to pay copyright holders for performing his songs at concerts. Corporate copyright is well developed and various aspects are spelled out in detail, as ownership, use, broadcast, or profit.

Therefore, despite the process of convergence of legal systems and the institution of copyright, in particular, authors need to carefully study the features of their legal field so that there are no unpleasant surprises. We will consider examples of the functioning on blogs of the continental copyright system below, and consider the Anglo-Saxon one in other articles.

\section{III.2. Historical Experience in Regulating Intellectual Property}

There is no single European practice for the development and reform of the intellectual property law system, each country chooses its strategy. However, the general course was chosen based on the modernization of legislation with an emphasis on online copyright protection, as technological progress and the development of the global Internet have led to the creation of new products, such as blogs, which are subject to copyright protection.

Consider in more detail the legislation of Germany. Germany began reforming its legislation in 2003, amending the previous 1965 copyright law.

According to Drobiazko (2019), a new legal act (in a study entitled "Reforming Copyright and Related Rights in Germany"): "was a response to the impact of digital technology on copyright and related rights law. This legislation was designed to bring German law under the requirements of the WIPO (2004) Copyright and Related Rights Treaty.

In particular, the new edition of the copyright law, which entered into force in Germany in 2008, imposes restrictions on copying and downloading computer data for non-commercial purposes and increases the financial burden on computer and printer manufacturers. The amendments to the law concern the right to make electronic and paper copies in the private sphere. Private use includes making copies for transmission to a narrow circle of people, family members, converting files to other formats, making backups of disks with software. These types of copying are permitted with new 
restrictions. The new version of the law prohibits copying CD and DVDs if they have a special protection program installed. It has become illegal to copy data that was downloaded or illegally copied by the distributor. This prohibition also applies to users of file-sharing systems.

Such "modernization" has made it possible to protect copyright, in particular for bloggers on the Internet in the early stages of globalization. That is, copyright in Germany has been protected since the beginning of the active use of the Internet. For comparison, in Ukraine, the Law "On Copyright and Related Rights" (1993) following the current development of the network was amended only in 2017, which made it impossible for a long time for Ukrainian authors to protect the products of their creative, intellectual activity. However, this is not the only aspect to pay attention to and adopt foreign experience.

Under the obligations arising from the EU Directive 2001/29/EC of 22 May 2001, the German legislature introduced a regime of legal protection $(\S \S 95 \mathrm{a}-95 \mathrm{~d})$ and remedies $(\S 108 \mathrm{~b}$ and $\S 111 \mathrm{a})$, which prohibits the circumvention of mechanisms designed to protect works and other materials from unauthorized copying (Drobiazko, 2019).

This solution protects copyright objects, in particular on the Internet, from plagiarism and guarantees that bloggers can protect their content. Borrowing such experience from Ukraine would contribute to the improvement of national legislation.

Another European country whose intellectual property rights should be mentioned is France. In 1992, the French Parliament adopted the Intellectual Property Code, which is evidence that this industry is at the forefront of government regulation. This approach to the systematization of legislation avoids conflicts between national norms of different branches of law and significantly reduces gaps in the legal system of the country.

The only country where intellectual property rights have been discussed since the Constitution is the United States (1787) (Article 1, Section 8, Clause 8, known as the Copyright Clause). The precedent system of the American law of the XX-XXI centuries has identified the biggest problems that arise in the United States in the field of copyright. The first is the concept of "contributory infringement". Its essence is that the person who contributes to copyright infringement will bear the same responsibility as the infringer himself/herself. An example of this doctrine is found in Gershwin Publishing Corp. v. Columbia Artists Management, Inc. (1971): "Anyone who, knowing of an illegal activity, incites, causes or materially contributes to a violation committed by another person may be prosecuted as a "contributing" violator". 
Another concept is called "vicarious infringement". The bottom line is that the manager is responsible for copyright infringement by his subordinates. An example is the case Dreamland Ballroom, Inc. v. Shapiro, Bernstein \& Co. (1929).

A review of international experience provides an opportunity to reasonably fill gaps in national legislation. This approach is appropriate because it allows reducing own state resources to find optimal solutions to problems in the field of intellectual property.

\section{III.3. Blog Copyright}

Active changes in the organization of society due to the widespread use of Internet resources has led to the emergence of new products in the field of intellectual property, one of which is a blog.

However, is it possible to put blogs of famous public people and organizations with unique content and pictures with kittens of anonymous users on Facebook on a par? We believe that, purely legally, these phenomena are equal to each other based on the current legislation that governs copyright.

So the main features of a blog are the presence of short text and/or the use of multimedia, including photos or videos. According to Article 2 of the Berne Convention for the Protection of Literary and Artistic Works (1886), Article 8 of the Law of Ukraine "On Copyright and Related Rights" and Article 433 of the Civil Code of Ukraine, photographic works are protected as objects of copyright. Moreover, the fact of publication, completeness, purpose, or genre of the photo does not affect the scope of legal protection.

For any use of the photo (except for certain cases of free use of works), you must obtain the consent of the copyright owner with the simultaneous payment of the copyright fee to him. But even if such use falls under the cases of free, the Law obliges to indicate the name of the author and the source of such borrowing.

Therefore, the results of activities related to the creation of articles and other written works, audiovisual works, and photographic works are protected by law as objects of intellectual property rights.

If a blogger uses self-made photos, videos, and handwritten texts when creating publications, i.e., he/she has the copyright to the constituent elements of such publication, it follows that the copyright for the publications and the blog as a whole belongs to the author of the texts, photos, and video, i.e., blogger. Typically, this method of blogging is used on social networks. However, there is another type of blog, which is not posted on social networks, but directly on the World Wide Web in the form 
of web pages, which are combined into a personal site with the help of navigation hyperlinks.

In Article 1 of the Law of Ukraine "On Copyright and Related Rights", the legislator defined a web page, namely as an integral part of a website that may contain data, electronic (digital) information, other objects of copyright, and (or) related rights, etc.

Quite often, blogs that are in the form of a web page may use photos, videos, or other works that are subject to copyright under Art. 433 of the Civil Code of Ukraine and Article 8 of the Law of Ukraine "On Copyright and Related Rights", the authors of which are not the author of the blog. If a blogger owns such works based on property rights (according to Article 419 of the Civil Code of Ukraine) or legally uses and distributes them, then the author of the blog may use works based on related rights, according to Art. 37 of the Law of Ukraine "On Copyright and Related Rights".

Thus, we have a somewhat confusing, but fairly complete national legal framework regarding copyright.

\section{III.4. Online Copyright Infringement}

To successfully implement their ideas, the blogger must eliminate all possible risks associated with plagiarism and other infringements of intellectual property rights. The most common copyright infringement that a blogger may face is the plagiarism of texts and illegal use of his photos.

Plagiarism has become a very important problem due to the uncontrolled movement of information on the Internet, the volume of which is constantly increasing (Kovalenko, 2018).

According to Art. 50 of the Law of Ukraine "On Copyright and Related Rights", plagiarism-publication, in whole or in part, of another's work under the name of a person who is not the author of this work. In practice, the following types of plagiarism are distinguished: complete copying of another author's work and its publication under one's name; copying a part of another author's work and publishing it under his/her name without a properly citation; paraphrasing the work of another author in the absence of a properly executed link.

Novels, poems, articles, and other written works, under paragraph 1. Part 1 of Art. 433 of the Civil Code of Ukraine are objects of copyright and therefore are protected from illegal use by others without the permission of the author. Social media posts or articles on a blogger's website are literary works and are therefore defined by civil law as objects of intellectual property rights. However, following Art. 10 of the Law of Ukraine "On Copyright and Related Rights" the legislator determines the conditions- 
restrictions under which articles are not subject to copyright, protected from encroachment. In particular, these include news reports of the day or current events that have the character of ordinary press information; works of folk art (folklore); official documents of political, legislative, administrative nature (laws, decrees, resolutions, court decisions, state standards, etc.) issued by public authorities within their powers and their official translations; state symbols of Ukraine, state awards; symbols and signs of state authorities, the Armed Forces of Ukraine and other military formations; symbols of territorial communities; symbols and signs of enterprises, institutions and organizations; banknotes; vehicle schedules, TV and radio schedules, telephone directories and other similar databases that do not meet the criteria of originality and which are subject to the right of sui-generis (a kind of right, the right of a special kind).

Particular attention should be paid to publications that contain news reports of the day or current events or events that have the character of ordinary press information because in this case there are some exceptions. If the blogger covers information that complies with Article 10 of the Law of Ukraine "On Copyright and Related Rights", in particular, briefly and essentially describes the actual news of the day or other current event, then such publication is not subject to copyright, and, accordingly, this information may be used and disseminated by others. However, if a blogger publishes an article that highlights his or her position on such an event, the publication will be subject to copyright and may be used by others only under applicable law, i.e., with the author's permission or indication of the original source.

The use of free, open, or limited licenses, when the owner of a work permits copying, distribution, home use, or other possible rights to an unlimited number of persons, partially relieves tension in this issue. On the one hand, this allows you not to worry about potential numerous violations and focus only on serious violations, for example, when someone improperly claims authorship or exclusive rights. Well combined with this approach is the low price or its absence at all and work by subscription or by the system of crowdfunding, "donations".

Quite often in the space of the Internet, there is a violation of copyright through the misuse of photographs.

Photographic works, in particular works made in methods similar to photography, following $\S 10$ of Part 1 of Art. 8 of the Law of Ukraine "On Copyright and Related Rights" refer to the objects of copyright. The exclusive right to permission or prohibition of the use of the work by other persons following Part 1 of Art. 15 of the same legal act, belongs to the author. 
National legislation on intellectual property, namely Art. 11 of the Law of Ukraine "On Copyright and Related Rights", establishes the presumption of authorship, which is that the primary subject to which the copyright belongs is the author of such work. If there is no other evidence, the author of the photograph will identify the person whose signature or name appears on the original or copy of such photographic work. This presumption also applies to social networks and the entire Internet space in general. That is if a blogger posted a photo on his page on social networks or a web page, the presumption of authorship applies - the author of the photo is the author of the blog.

In this case, the person whose copyright has been infringed has the right to apply to the court to restore his infringed right, and the court, in turn, will rule and recognize the copyright in the photograph of the person who first published it.

If the publication takes place by a person who does not own the rights to such a photo, then we act oppositely, the claimant-copyright holder must prove his right to the photo. This can be done in different ways.

The date of publication will be used as appropriate evidence. Another crucial piece of evidence in the above dispute will be the presence of the author of the original - the original photo (without the use of software processing). It is also worth noting the provisions of the Supreme Court Judgment of November 27, 2018, in case $\mathrm{n}^{\circ}$ 914/2505/17, which states that photographs and videos may be proof of copyright only if they comply with electronic evidence (in particular, recording the date and shooting time, scene, etc.). Copyright infringement on the Internet due to the misuse of photographs is quite common in Ukraine, as evidenced by the existence of court precedent, such as case $n^{\circ} 332 / 2917 / 18$, which was pending in the Zavodskyi District Court of Zaporizhzhia. In this case, a violation was considered, which consisted of the misuse of photographic works published on the Internet. The consequence of such consideration is the termination of the infringement and the restoration of the infringed copyright.

The next example is litigation $\mathrm{n}^{\circ} 2-2186 / 07$. The Donetsk District Court considered the violation, which consisted of plagiarism of articles posted on the website. The copyright of the author of the articles was restored, and the offender was charged compensation for copyright infringement for 210,000 (two hundred and ten thousand) hryvnias.

Other problems that a blogger who has published a product of his creative activity on the global network may face are the cross-border nature of the use of copyright objects; inability to track who and how the publication or its elements will be used; lack of an effective copyright protection mechanism online. 
The cross-border nature of the use of intellectual property through the Internet, in turn, is that from the moment a photo, video, text, or other work is published, it is shared worldwide, not only in a state whose legislation should be applied to resolve possible conflicts. Therefore, there may be a legal conflict and the object of copyright used through the network in the territory where the relevant rules of law do not apply.

Article 5 of the Law of Ukraine "On Copyright and Related Rights" establishes the procedure for applying the rules of an international agreement in case of conflict of provisions of such agreement with the legislation of Ukraine in the field of copyright, however, in Ukraine there is no normative legal act that would regulate the problem of the absence in foreign legislation of the norm of intellectual property law, which is contained in the national one.

In general, the problem of abuse by the "alleged author" and the assignment of such a status to them, without being in fact, persists and intensifies. Legislation, of course, established that in the absence of evidence to the contrary, the person indicated on the original or copy of the work (the so-called "Presumption of Authorship") is considered the author of the work. But such a legal category turns out to be very controversial in practice, and very often the courts interpret it differently: for example, they do not require the author to prove his authorship for work, or, conversely, refuse a claim due to the lack of evidence of such authorship.

\section{III.5. Ways to Protect Content}

Every author wants to protect his work or other product of intellectual activity as the most reliable, and later to commercialize the embodied ideas. Any investor wants to fund only in copy-protected projects (Niculesco, 2019).

Unfortunately, modern Ukrainian legislation in the field of intellectual property does not establish reliable protection of content. Therefore, it is important to discuss possible options for protecting the copyright of bloggers and strategies to restore rights in case of violation.

First, the concept of "content" should be defined. According to the dictionary, content is a direct tracing of English. This is a collective term for any information contained in an information resource. When it comes to web resources, the better it is, the more beneficial for site promotion (iGroup, 2020).

There are different approaches to the regulation of intellectual property law. They are usually classified as "strict" and "soft". The "strict" should include clear, statutory prohibitions. Liability (usually in the form of penalties) is established for non-compliance with the provisions of such regulations. The "soft" include such methods as the purchase of property 
copyright or related rights, attracting subscribers (persons who follow the status updates or news feed of another user, in particular, a blogger), or the use of a system of "donors" - payment in real terms virtual privileges. In turn, blogs are also classified by subscriber size and purpose into personal and professional. The distinction between professional and personal blogs is usually made according to the standards set by a particular Internet platform. For example, in the social network Instagram certain functions for blogging become available to the user only after gaining more than ten thousand subscribers, which can be argued that for this social network, the distinction between professional and personal blogs depends on the number of subscribers. Professional blogs should be protected using only "strict" approaches because it is the publications of professional blogs that are subject to the largest and most frequent infringement of copyright. There will be enough "soft" means for the protection of personal blogs.

It is worth noting that social networks use certain methods aimed at protecting copyright. Each network has "its own policy". For example, the policy of the social network Facebook is based on the interest in avoiding copyright infringement. The site administration has created tools to help protect intellectual property rights. Also, for additional information, there is a special page of the help center for intellectual property infringement. If Facebook users notice violations, they contact the site administrator with a message. As a result of reviewing such a message, the Facebook administration must remove the illegally posted work. For systematic violators, the application of a sanction in the form of blocking their account (personal page) is provided. The next popular platform for bloggers to realize their creative potential is YouTube. The YouTube service has a mechanism for the ability to control their content copyright, with which you can perform the following actions: send a message about the alleged copyright infringement; submit a counter-notification; send a request to remove content that illegally uses your materials; send a request for recovery, mistakenly deleted video; send objections; withdraw a claim, complaint, etc. If you submit a complaint to the site administration, YouTube will conduct its own investigation and remove the content in question if the violation is confirmed (Ilchuk, 2019). Such protections are not effective enough, as the maximum liability of the infringer will lie only in the deleted posts that infringe someone's copyright.

Copyright registration is certainly the most effective way to protect copyright from infringement; however, it is not the best way from a blogging perspective. Besides, the current legislation does not require mandatory registration of copyright to a particular work. The author, in turn, acquires copyright from the moment the work is created. Unscrupulous persons, 
taking advantage of such a legal situation, can appropriate the results of intellectual activity of other authors. Therefore, there are some difficulties with proving the fact of authorship, which indicates the need to secure it.

The next effective means of security is the mandatory indication of the author's name. Following the provisions of paragraph 3 of Part 1 of Art. 14 of the Law of Ukraine "On Copyright and Related Rights", the author has such a personal intangible right as to choose a pseudonym, indicate, and require the indication of the pseudonym instead of the real name of the author on the work and its copies and during any public use.

Following Part 1 of Art. 11 of the Law of Ukraine "On Copyright and Related Rights", the primary subject to which the copyright belongs is the author of the work; also, this provision applies in the case of publication of a work under a pseudonym that identifies the author. A very important aspect is the ability to identify the author by pseudonym.

If a blogger uses an alias that is not close to his or her real name, there may be further difficulties in proving that such a blog belongs to that person. The best way to protect yourself from the above situation is to sign each post with your real name, in case the blogger uses a pseudonym. Also, this situation has another approach to solving - registering your nickname as a blogger. A blogger who is very popular and profitable can register his nickname as a trademark. This can be done using the International Standard Name Identifier. It is a system for uniquely identifying creators, publishers, and such types of media content as books, television programs, newspaper articles, and others, which have shown their effectiveness today (Gatenby, 2015).

An effective way for a blogger to protect their photographic and audiovisual works is to preserve their originals, i.e., those original versions that have not been technically processed. Such photos, as mentioned earlier, will serve as significant evidence in the event of a lawsuit.

Another preventative way to protect photographic and audiovisual works is to use watermarks by the blogger. This approach will not only reduce the likelihood of plagiarism but will also serve as substantial proof of authorship in the case of litigation.

Services such as archive.org are also gaining popularity, which make backups of various parts of the internet, where you can independently upload your data for free as a preventive measure and in the future, in case of disputes, refer to this resource.

Quite often in legal advice, you can find advice for authors to send a manuscript to your mail. The date of receipt of the envelope with such a work is considered substantial evidence in court if it is necessary to justify to the author the date of creation of the object of his copyright. For bloggers, this advice to keep content from being compromised can also be helpful. 
However, in case of protection of his copyright, the blogger should send himself a mail (or e-mail) "screenshot" (an image obtained by a computer that really depicts what the user sees on the monitor screen) of their posts.

Undoubtedly, most often for protection and demand the restoration of violated rights, including copyright, the victim of the offense goes to court. However, this method has several disadvantages, which in some cases can worsen the situation of the person or persons who have suffered harm. The first and most important disadvantage is the waste of time on the trial, which can last from several months to several years. Taking into account the norms of the Civil Procedure Code of Ukraine, such consideration will last at least 90 days. Another disadvantage of this approach is the excessive costs associated with litigation, the involvement of experts, legal aid, and other aspects. That is why the method of settling disputes out of courtmediation - is becoming increasingly popular in the world. As noted by Motuzka and Samelyuk (2019) in the study "Extrajudicial methods of dispute settlement in the field of intellectual property": "Mediation is an optional, special, non-coercive, flexible and closed mechanism for reducing the level of uncertainty and risks between the parties," they said.

The advantages of mediation are the saving of such resources as time and money. As of July 2020, no law in Ukraine would specifically regulate the activities of mediators, however, there is a Bill of December 17, 2015, $n^{\circ} 3665$ "On Mediation", the adoption of which would greatly facilitate outof-court settlement of disputes, in particular in the field of copyright protection.

Each problem requires a special approach to solving it. Anticipating possible future infringements and finding ways to protect them in advance is the best way to protect a blogger's copyright from encroachment. However, at present in Ukraine, there is no specially created body of state power to which one could turn in cases of exclusively intellectual law. Therefore, at the moment, the best and most effective way to protect and restore an already infringed copyright of a blogger is to go to court with a statement of claim.

\section{III.6. The Realities of Today}

In 2019, Ukraine was tasked to begin reforming intellectual property legislation. This reform was to make changes from the activities of patent attorneys to the activities of judges. Ukraine has chosen to move towards setting European standards. However, over several months, the reform slowed down, and numerous bills were never passed by the Verkhovna Rada of Ukraine. 
The State Intellectual Property Service of Ukraine was liquidated, but the complete reorganization of the sphere of public administration was not completed. Today, the issue of implementing a transparent two-tier structure of the state system of the legal protection of intellectual property remains open (Niculesco, 2019).

In February 2020, the Supreme Court of Intellectual Property was registered following Art. 147 of the Law of Ukraine "On the Judiciary and the Status of Judges" (2016). As of July 2020, the court has not started its activities, as the formation of judges on a competitive basis continues. It is worth noting that this state institution was established in 2017, as a result of judicial reform in 2016. There are no clear predictions when the Supreme Court of Intellectual Property will start working.

A very important obstacle to reform was the spread of coronavirus disease (Covid-19) in March 2020. The pandemic slowed down parliament's efforts to revise and amend intellectual property laws, as all attention and public resources were focused on combating the spread of the disease.

In June 2020, the Verkhovna Rada of Ukraine adopted Law 2255 "On Amendments to Certain Legislative Acts of Ukraine Concerning the Establishment of a National Intellectual Property Body (NIPB)" (State Enterprise "Ukrainian Institute of Intellectual Property", 2020). As Kozhokar (2020) notes in the article "Intellectual Property Protection Reform: Establishment of NIPB" on the prospects of entry into force of the above law: "It is expected that the adoption of the Law will create a transparent and effective structure of intellectual property management. Deadlines for issuing security documents, to introduce effective mechanisms for the protection of intellectual property rights, which in turn will create conditions for the development of a national innovation system and improve the investment climate in Ukraine."

Such changes are also necessary for bloggers who want to properly protect the copyright of their content. After all, in the absence of proper state control, it is impossible to talk about guarantees of protection of intellectual property rights by the state. That is why today in Ukraine there are several difficulties in the implementation of copyright protection.

Also, a positive prospect for Ukrainian bloggers will be the adoption, as of July 2020, of the Bill 2693 "On Media". "The National Council on Television and Radio Broadcasting will regulate not only those it licenses and registers but any media entities, including online media, telegram channels, bloggers and video bloggers. This follows from the norms of the draft law "On Media" - this explanation was given by Burmagin, a member of the working group that worked on the above-mentioned draft law (Zakusilo, 2020). 
Registration of online media will allow the state to regulate and prevent content violations, to bring online offenders to justice. Today, if there is a copyright infringement online, the blogger does not know which body to file a complaint with, as there is no such body. The draft law "On Media" determines the ability of the regulator in case of content violations to respond based on its own monitoring or statements of victims. Also, the Bill imposes significant fines (from 1 to 5 minimum wages) for the above violations. Such a strategy will serve as an effective means of deterring mass violations.

\section{CONCLUSIONS}

As a result of the study, the following conclusions can be drawn.

1. The rapid development of digital technologies and the promotion of the global Internet have made numerous adjustments in the field of intellectual property. The advent of the blog led to the rapid creation and distribution of content. Moreover, by constantly creating and filling blogs with relevant information, Internet users often act as both authors and consumers. Because of these changes, the network user has difficulty distinguishing between copyright and non-copyright. Undoubtedly, the best solution to this issue is to study bloggers as participants in legal relations in the field of intellectual property.

2. Copyright is one of the inalienable and inalienable human rights. The right to freedom of opinion and expression is guaranteed by international regulations ratified by the Parliament of Ukraine. The right of a person to the result of intellectual, creative activity or another object of intellectual property rights is endorsed by national legislation. However, in the context of globalization and convergence of legal systems and the institution of copyright, in particular, authors need to carefully study the peculiarities of the legal regulation of the services with which they work, since there are serious differences in understanding the details and ways of working with different approaches in understanding copyright.

3. The most popular problems that a Ukrainian blogger may face is the low level of content protection, which means that plagiarism of texts, photos, or other works and difficulties in copyright protection in case of infringement are quite common. A successful solution to the problem of weak protection should be the creation of the proposed two-tier structure of the state system of the legal protection of intellectual property.

4. Currently, there are two ways to resolve disputes in Ukraine that arise in the event of copyright infringement by bloggers. The first way is to 
contact the site administration, where the author carries out his blogging activities. The policy of each site separately has its own strategy to restore the violated right. Usually, due to the fact of violation, the site administration forcibly removes the publication of the offender. Another and at the same time, the most effective solution to restore infringed copyright in Ukraine is the classic way of settling disputes, in court. In the case of copyright infringement, the injured party may apply to the court of the first instance. As a result of such actions, court proceedings will be opened, which will result in a court decision aimed at restoring the violated right and punishing the offender.

5. The best, an alternative to the classic court, way of resolving disputes in the field of intellectual property for bloggers, in the case of the adoption of the Draft Law "On Mediation", will be to apply for out-of-court settlement of disputes, in particular, to a mediator. It is this method that will ensure a speedy resolution of the case and help save money that would have to be spent on court costs and court fees if the injured party chose the traditional approach to resolving disputes in Ukraine.

6. Ukrainian legislation in the field of intellectual property, of course, needs to be reformed. In 2019, the first actions aimed at improving and modernizing national legislation began, but the reform was suspended. A major obstacle to the implementation of the plans and the achievement of the set goals was the pandemic of the coronavirus disease Covid-19 in March 2020 , as all the attention and resources of the country were focused on preventing the spread and overcoming of the above disease. As of July 2020, the Verkhovna Rada of Ukraine has the Bill "On Media", which will pass positive changes in the field of intellectual property and copyright.

7. Ukraine is not the only country that has undergone reforms in the field of intellectual property and copyright. The numerous experiences of other countries that have already introduced the necessary norms for modern society into their legislation can be a good example. One of the European countries, on the experience of which it is worth relying on, is Germany, because by making certain changes in the legislation, this country was able to establish appropriate guarantees and copyright protection on the Internet. 


\section{REFERENCES}

Aksyutina, A. V., Nestertsova-Sobakar, O. V. \& Tropin, V. V. (2017). Intellectual Property. Dnipro: Dnipro State University of Internal Affairs.

Baldwin, P. (2014). The Copyright Wars: Three Centuries of Trans-Atlantic Battle. Princeton University Press. In https://www.jstor.org/stable/j.ctt6wq0z2.4?seq=1\#metadata_info_tab_contents,

Bently, L., Sherman, B., Gangjee, D. \& Johnson, P. (2018). Intellectual Property Law. Oxford University Press. DOI: 10.1093/he/9780198769958.001.0001.

Convention for the Protection of Human Rights and Fundamental Freedoms as amended by Protocols $\mathrm{n}^{\circ} 11$ and 14 (1950).

Cox, A. M. \& Blake, M. K. (2011). Information and food blogging as serious leisure. Aslib Proceedings, 63(2-3), 204-220. doi: 10.1108/00012531111135664.

Drobiazko, V. (2019). Reforming copyright and related rights in Germany. Theory and practice of intellectual property, 6, 15-23. doi: 10.33731/62019.187731.

European Union. (2001). Directive 2001/29/EC.

France. (1992). Intellectual Property Code. In https://internetlaw.ru/law/int/nation_cleo/france/fr003en.pdf.

Gatenby, J. (2015). I2 and ISNI: Expanding the Use of an Identifier to Serve Multiple Needs. In A. Todd (ed), The Critical Component: Standards in the Information Exchange Environment. In https://www.researchgate.net/publication/280566836_I2_and_ISNI_Expanding _the_Use_of_an_Identifier_to_Serve_Multiple_Needs.

Germany. (1965). Act on Copyright and Related Rights. In https://www.gesetze-iminternet.de/englisch_urhg/englisch_urhg.html.

Grigorenko, A. (November 11, 2019). Ways to protect copyright to the work. Protocol. In https://protocol.ua/ua/sposobi_zahistu_avtorskogo_prava_na_tvir/.

iGroup. (2020). Site content. In https://igroup.com.ua/seo-articles/kontent/.

Ilchuk, M. (2019). Features of liability for infringement of intellectual property rights in social networks. IP Company “GoldMark”. In http://torgmarka.ua/ua/zahistprav/osoblivosti-vidpovidalnosti-za-porushennya-prav-intelektualnoyivlasnosti-v-sotsialnih-merezhah.html.

Kaminsky, M. (November 12, 2020). Blogging and Intellectual Property Law. LegalZoom. In https://www.legalzoom.com/articles/blogging-and-intellectualproperty-law.

Koval, M. (April 4, 2020). How to secure your copyright? League.Blogs. In https://blog.liga.net/user/mkoval/article/36320.

Kovalenko, I. A. (2018). Actual problems of protection and protection of intellectual property rights on the Internet in the context of globalization of society and modern technologies. Scientific notes of the Tavriya National University named 
after V. I. Vernadsky. Series: Legal Sciences, 29(68/3), 52-55. In

http://nbuv.gov.ua/UJRN/UZTNU_law_2018_29\%2868\%29_3_11.

Kozhokar, O. (June 22, 2020). Reform of intellectual property protection: the creation of the National Intellectual Property Body. Legal Gazette. In https://yurgazeta.com/dumka-eksperta/reforma-zahistu-intelektualnoyi-vlasnostistvorennya-noiv.html.

Liptsik, D. (2002). Copyright and related rights. Lawbook. In https://lawbook.online/rossii-pravo-avtorskoe/avtorskoe-pravo-smejnyieprava.html.

Matveev, A. (2009). Some Comparative Legal Aspects of the Anglo American and Romano German Copyright Concepts. Perm University Herald. Juridical Science, 4(6). In http://www.jurvestnik.psu.ru/index.php/ru/vypusk-4-62009/10-2010-12-01-13-31-58/-4-6-2009/203-nekotorye-sravnitelno-pravovyeaspekty-anglo-amerikanskoj-i-romano-germanskoj-konczepczij-avtorskogoprava.

Moroz, P. (March 15, 2019). How to protect your copyright on the Internet? LexInform. In https://lexinform.com.ua/yuridychna-praktyka/yak-zahystyty-svoye-avtorskepravo-v-interneti/.

Motuzka, K. A. \& Samelyuk, O. S. (2019). Extrajudicial methods of dispute resolution in the field of intellectual property. Interregional Academy of Personnel Management, 1, 113-120. DOI: https://doi.org/10.32689/2617-9660-2019-3-1113-120.

Nedoinov, K. V. \& Kruglova, O. O. (2019). Comparative analysis of copyright in Ukraine and the USA. Materials of the All-Ukrainian scientific-practical seminar, 152153. In http://er.dduvs.in.ua/bitstream/123456789/4822/1/45.pdf.

Niculesco, D. (April 5, 2019). There will be no new strategy for the development of intellectual property? Zn.Ua. In https://zn.ua/ukr/macrolevel/novoyi-strategiyirozvitku-sferi-intelektualnoyi-vlasnosti-ne-bude-307764_html.

Nyon, A. (1846). Droits civils des auteurs, artistes et inventeurs. Paris: Joubert.

Rishkova, O. V. (2007). Protection of intellectual property rights under the civil legislation of Ukraine. Odessa: National University "Odessa Law Academy".

Safarov, A. (May 20, 2020). How to protect the copyright of a photograph. Institute of Mass Media. In https://imi.org.ua/monitorings/yak-zahystyty-avtorske-pravona-fotografiyu-i33190.

State Enterprise "Ukrainian Institute of Intellectual Property". (2020). The law on the establishment of a national intellectual property body has been adopted. In https://ukrpatent.org/uk/news/main/noiv-law-16062020.

Svitlychny, O. P. (2016). Intellectual property law. Kyiv: National University of Life and Environmental Sciences of Ukraine.

The Cambridge Dictionary. (2020). "Blog". In http://dictionary.cambridge.org/dictionary/british/blog_1. 
The Macmillan Dictionary. (2020). "Blog”. In http://www.macmillandictionary.com/dictionary/british/blog.

Ukraine. (1993). On copyright and related rights: Law 3792-XII. In https://zakon.rada.gov.ua/laws/show/3792-12\#Text.

Ukraine. (1996). Constitution of Ukraine. In https://zakon.rada.gov.ua/laws/show/254\%D0\%BA/96$\% \mathrm{D} 0 \% \mathrm{~B} 2 \% \mathrm{D} 1 \% 80 \#$ Text.

Ukraine. (2003). The Civil Code. In https://zakon.rada.gov.ua/laws/show/43515/conv\#Text.

Ukraine. (2004). Civil Procedure Code of Ukraine: Law 1618-IV. In https://zakon.rada.gov.ua/laws/show/1618-15.

Ukraine. (2005). Code of Administrative Procedure of Ukraine: Law 2747-IV. In https://zakon2.rada.gov.ua/laws/show/2747-15.

Ukraine. (2016). On the judiciary and the status of judges: Law 1402-VIII. In https://zakon.rada.gov.ua/laws/show/1402-19.

Ukraine. Donetsk District Court. (2007). Judgment 2-2186/07. In https://reyestr.court.gov.ua/Review/4556453.

Ukraine. Supreme Court. (2018). Judgment 914/2505/17. In https://verdictum.ligazakon.net/document/78450568.

Ukraine. Zavodskyi District Court of Zaporizhzhia. (2018). Judgment 332/2917/18. In https://reyestr.court.gov.ua/Review/77404359.

United States. (1787).Constitution. In https://www.senate.gov/civics/constitution_item/constitution.htm\#a1.

United States. (1976). Copyright Law of the United States. In https://www.copyright.gov/title17/.

United States. Circuit Court of Appeals. (1929). Dreamland Ball Room v. Shapiro, Bernstein CO. In https://www.casemine.com/judgement/us/5914a690add7b049346dd1f4.

United States. Court of Appeals for the Second Circuit. (1971). Gershwin Publishing Corporation v. Columbia Artists Management, Inc., Defendant-appellant, Andcommunity Concerts, Inc. In https://law.justia.com/cases/federal/appellatecourts/F2/443/1159/246268/\#fn8.

United States. Massachusetts District Court. (1845). Davoll et al. v. Brown. In https://law.resource.org/pub/us/case/reporter/F.Cas/0007.f.cas/0007.f.cas.0197. pdf.

USA. Southern District of New York. 2017. McCartney v Sony/ATV Music Publishing LLC et al.: case No. 17-00363. In https://www.pacermonitor.com/public/case/20376762/MCCARTNEY_v_Sony ATV_Music_Publishing_LLC_et_al. 
WIPO. (1886). Berne Convention for the Protection of Literary and Artistic Works. In https://www.wipo.int/treaties/ru/ip/berne/index.html.

WIPO. (2004). Guide to the Copyright and Related Rights Treaties Administered by WIPO and Glossary of Copyright and Related Rights Terms. In https://www.wipo.int/publications/en/details.jsp?id=361\&plang=EN.

Zakusilo, M. (January 30, 2020). Under the new law on media bloggers and unregistered online media will also be regulated by the National Council. Media detector. In https://detector.media/infospace/article/174356/2020-01-30-za-novimzakonom-pro-media-blogeri-ta-nezareestrovani-onlain-media-tezhregulyuvatimutsya-natsradoyu/.

Zerov, K. (February 18, 2018). Indirect copyright infringement: US case law. Protocol. In https://protocol.ua/ua/nepryami_porushennya_avtorskogo_prava_sudova_prakti ka_ssha/.

Zozulya, N. (May 2, 2019). Copyright protection: practical aspects. Ukrainian law. In https://ukrainepravo.com/law-practice/lawyers-practice/zakhyst-avtorskykhprav-praktychni-aspekty-/. 